\title{
ТЮРКІЗМИ В ТОПОНІМІЇ УКРӒ̈НИ: ІСТОРИКО-ЕТИМОЛОГІЧНИЙ АСПЕКТ
}

Міграція з Алтаю в Південну Європу поліетнічних войовничих гунів, основу яких становили тюркські племена, спричинилася до перших масових поселень носіїв тюркських діалектів і мов на території сучасної України у IV-V ст. н. е., але мовних слідів їхнього перебування тут, зокрема в місцевій топонімії, майже не збереглося. Основними причинами такого стану є дві: 1) тогочасні (пізні) праслов'яни і тюрки ще не мали писемності, яка б дозволила зафіксувати вживані місцевим і прийдешнім населенням бодай найвідоміші власні географічні назви; 2) після занепаду гунської держави і зміцнення східнослов'янського Антського союзу тюркський вплив на формування місцевої топонімії протягом кількох наступних століть був мінімальним. Із певними застереженнями до імовірних тюркських рефлексів середини I тисячоліття н. е. в українській топонімії можна віднести основу слов'янізованої назви р. Бія́нка, що в сучасному Кіровограді, яка походить від тюрк. бій «повелитель, глава племені, вождь тощо» і ян «сторона, бік, навколишня місцевість». Вона має паралелі в Башкортостані та в Челябінській обл. Росії і може відбивати віддалений зв'язок з назвою алтайської р. Бія́ < бӓj-/бій- «високий» (ЕСТУ: 53), з басейну якої гуни мігрували у свій час на захід. Щоправда, гідрооснова Біян- може бути і наслідком пізнішої тюркської адаптації давнішого слов'янського гідроніма $з$ основою псл. *bijanъ «битий, молочений, зруйнований; той, кого з силою виштовхнули назовні (про струмінь води)», утвореного як пасивний дієприкметник на *-janъ від *bijati < *biti «бити»; пор. нижньонаддніпрянське вибіяний «вибитий, штампований» (Лучик 1999: 32-36) і зх.укр. бия̀нка, біє̀нка, бія̀нка «посудина для збирання масла» (Аркушин 1: 20), яке могло розвинути географічне значення «водойма, подібна до посудини; річка зі збитою бурхливою водою» і мотивувати назву невеликого водного об'єкта подібно до гідронімів Макі́mра, Ти́ква (див. ЕСТУ: 53).

Починаючи з IX-X ст. багатовікові контакти тюркських племен і народів 3 корінним населенням Південної Русі широко відбилися в її топонімії, у якій тюркізми становлять одну з найчисельніших груп іншомовних географічних назв. Вони закріплювалися в місцевому мовленні протягом трьох основних періодів: 1) київськоруського (давньоукраїнського) - IX-XIII ст., коли точилася боротьба

* 04655, Київ, вул. Г. Сковороди, 2, Національний університет «Києво-Могилянська академія», к. 3, кімн. 203; vluchyk@meta.ua 
між східними слов'янами й тюрками за степові землі України, Крим та північне узбережжя Чорного моря; 2) староукраїнського - XIV-XVIII ст., що в основному збігається з функціонуванням Запорозької Січі та її мирним і військовим протистоянням з Кримськотатарським ханством і Османською імперією; 3) новоукраїнського (сучасного) - XIX-XXI ст., упродовж якого активне творення тюркських топонімів обмежувалося переважно територією Криму, де проживають кримські татари, й незначною частиною Південно-Західної Одещини, де є нечисленні поселення гагаузів.

За свідченнями «Етимологічного словника літописних географічних назв Південної Русі» (ЕСЛГНПР), який охоплює поширені на території сучасної України топоніми XI - початку XIV ст., у Київській Русі (давньоукраїнський період) функціонувало близько півтора десятка відомих географічних назв з основами тюркського походження. Їхня етимологія відбиває актуальні мотиваційні ознаки в межах основних принципів номінації, а саме: властивості географічних об'єктів: ур. Олькка у Волинській землі < тюрк. aloka «ущелина, яр» (ЕСЛГНПР: 94); відношення до інших фізико-географічних чи створених людиною об'єктів навколишньої місцевості: р. Каялы в Половецькому полі, букв. «скеляста» (про уз-

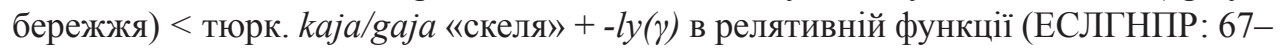
68); відношення об'єктів до людини чи людського суспільства (м. Тъмуторокань, $T(b)$ муторокань на Таманському півострові $<*$ Тъмуторкань < тюрк. tamantarkan «певний сан» 3 наступним приєднанням слов'янського посесивного суф. ${ }_{-j}$-jb $<$ *-jo- (Фасмер 4: 65); конотативні культурно-історичні або сакральні уявлення, які сформувалися на основі одного з попередніх принципів номінації: р. Осколь л. Сіверського Дінця, букв. «Сто річок» < тюрк. *Аз кол, де аз «сто» - нумеративний член у сакрально-символічному значенні, a gol «рукав, відгалуження» (ЕСЛГНПР: 96), «озеро, річка»; пор. укр. топоніми Стохід, Стонога, Стоколос, Сто могил, що виникли за аналогічною образною ознакою (ЕСТУ: 365), актуальною і в інших індоєвропейських мовах (Шульгач 1998: 274).

Незалежно від походження топоніми як своєрідні знаки-символи окремих географічних об'єктів не потребують перекладу при вживанні носіями різних мов, що відрізняє їх від апелятивів і забезпечує їм вищу стійкість порівняно з загальними назвами. Однак відповідний переклад топонімів унаслідок міжмовних контактів східнослов'янських і тюркських племен подекуди мав місце. Зокрема, тюркська назва лівої притоки Дніпра Єрєль (суч. Оріль) виникла наприкінці XII

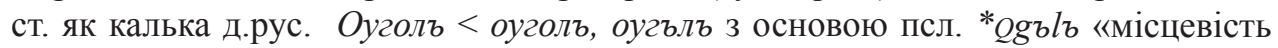
між річками, що сходяться» (ЕСТУ: 234), «ріг, кут, закрут»; пор. тюрк. airily «кутастий» (ЕСЛГНПР: 58, 164), що є дієприкметниковою формою з первинним значенням «розділений» дієслова аірыл/аіріл «розділятися, розходитися, утворювати кут» (ЕСТУ: 364).

На думку Ю. О. Карпенка, відбитий у гідронімі Оугъль (тюрк. Срель) образ малої батьківщини як «клину рідної землі між річками, що сходяться», який сформувався в середовищі давньоруських угличів (етнонім походить від топоніма Оугълъ), було перенесено спочатку в бас. р. Інгул (варіант Angul < псл. $\left.{ }^{*} Q g ъ l ъ\right)$, 
пізніше (в козацьку добу) в межиріччя Дунаю та Нижнього Дністра, де закріпилася турецька калька назви Буджа́к, а також у місце останньої міграції їхніх нащадків на Прикарпатті, де вони заснували поселення з відповідною українською назвою Ку́mú (< куm «вугол, тупик») і засвоїли територію Поки́mтя (< поку́mтя «місцевість по обидва боки кута, утвореного злиттям двох річок») (див. ЕСТУ: 78, 234, 297, 364-365, 383).

Явище давньорусько-тюркського калькування могло мати місце і в процесі формування назви р. Моло́чна, яка впадає в оз. Моло́чне, що в бас. Азовського моря: p. Молочьная < молочьная «мутна, подібна за кольором до молока» (ЕСЛГНПР: 89), хоч можливою $є$ мотивація назви конотативним значенням «поживна, щедра на ресурси» (пор. д.рус. фолькл. ргъки молочьныъ, берега кисельныи) або антонімічною семантикою «чиста», навіяною південно-східними впливами; пор. давньоруську фіксацію тюркської назви р. Сутгнн, яка впадає в оз. Моло́чне, < тюрк. süten «молочна» (ЕСЛГНПР: 150), а також відповідну основу в тюркському фольклорі та в індійській міфології, де існує опозиція молоко «чистий» і кров «нечистий», «що певним чином могло відбитися і в гідронімній типології великих азіатських регіонів» (Желєзняк 1987: 48).

Основна маса тюркізмів закріпилася в топонімії України в козацьку добу XVXVIII ст., коли в Південній Європі панувала Османська імперія. Як і раніше, такі географічні назви виникали за актуальними властивостями та ознаками самих об'єктів, їхнім відношенням до людей або до інших об'єктів, що зумовлено універсальністю відповідних принципів топонімної номінації, адже поза межами властивостей самих об'єктів, їхнього відношення до людей або інших об’єктів реальних мотиваційних ознак не буває. Зокрема, за внутрішніми властивостями географічних об'єктів постала етимологічно прозора назва суміжних р. і оз. Аджиго́ль у теперішній Одеській обл., яка мотивована основами аджи «киснути, бродити» і гол/голь < д.тюрк. köl «озеро, водойма» (ЕСТУ: 14-15), споріднена назва р. Аджа́мка л. Інгулу л. Пд. Бугу; Аджинка (1697), Adżamka (1880) (СГУ: 19; Лучик 1999: 24-25), в основі якої татарський або турецький дієприкметник аджим/аджин «зіпсований, прогірклий, скислий» (Радлов I/1: 525), що походить від д.тюрк. ас̆ї- «киснути, бродити» (ДТС: 4); слов'янський суфікс -к(a) в релятивній функції приєднано пізніше. Гідронім виник за актуальною для степових річок ознакою «вода, що гірчить, кисла, зіпсована тощо». Його структурні варіанти пояснюються у зв'язку з поширеним у діалектах тюркських мов чергуванням суфікса - - -/-м- і голосих -u-/-a-, що постали на основі давньотюркського дифтонга [уа]. Основа Аджи- наявна в багатьох гідронімах півдня України.

Частина тюркізмів увійшла в топонімію України не безпосередньо від носіїв тюркських мов і діалектів, а завдяки онімізації запозичених з відповідних джерел апелятивів, які давно були засвоєні носіями української та інших слов'янських мов. Таке закріплення географічних назв відбувалося навіть на територіях, де тюркський вплив був менш відчутним, ніж на півдні та сході України. Прикладом цьому є топоніми Майда́н у Західній Україні, які називають: 1) с-ще міськ. типу, Міжгірський р-н Закарпатської обл.; відоме з XVI ст. (ГЕУ 2: 315); 2) пагорби в 
Українських Карпатах на Івано-Франківщині (Габорак: 222). Ці назви виникли внаслідок онімізації апелятива майда́н «площа», діал. «лісова галявина; стародавня могила, розкопана зверху; рівне поле, низина, оточена лісом або будівлями», «смолярня», який запозичено з тюркських мов, де maidan «вільне, рівне місце» походить від перс. meidan «площа, арена» або від араб. таydắn «віддаль; обсяг, царина; місце для гри» (ЕСУМ 3: 361). Численні топоніми з основою ГТ майда́н поширені в тюркських, іранських, слов'янських, кавказьких, арабських мовах на відповідних територіях Євразії (Мурзаев: 358-359); пор. сучасний урбанонім Майда́н Незале́жності в Києві, який став символом демократичної України.

Універсальним для різних мов $є$ протиставлення об'єктів номінації за ознаками «білий, світлий, добрий» і «чорний, темний, поганий». Топоніми, особливо гідроніми, з відповідними основами поширені в усіх слов'янських і неслов'янських мовах. Зокрема, тюркізми з подібними мотиваційними ознаками закріпилися і в українській мові. До таких належать гідроніми Аксу́ - 1) ручай, л. Улу-Узеню бас. Чорного моря поблизу м. Алушти в Криму (СГУ: 20); 2) річка, назва Пд. Бугу в записах П. Маштакова (СГУ: 423), що виникли як композити на основі словосполучення, яке містить корінь ак з етимологічною семантикою «текти», пізніше — «білий», і су «вода», буквально «вода, що тече» (Мурзаев: 42). Стосовно гірських річок у Середній Азії, Азербайджані та інших краях, які мають прісну воду, відбулося переосмислення гідрооснови «біла, чиста вода» (Мурзаев: 43-44), що внаслідок міграцій зі сходу могло позначитися і на назвах українських водних об'єктів з проточною водою. Цьому сприяло одне із значень основи ак «білий, чистий» (Севортян: 116-117), яке в гідронімії зазнало подальшого семасіологічного переходу «білий, світлий» $\rightarrow$ «річка», зумовленого зоровим враженням; пор. аналогічне явище в європейській гідронімії, що зокрема відбилося в назві р. Ла́ба $(<$ псл. *Alba) в бас. Прип'яті, пол. Elba, нім. Elba (Шульгач 1998: 35).

Протилежну мотиваційну ознаку відбивають тюркські топоніми 3 основою кара- «чорний, темний», наявною, зокрема, в назві р. Карасівка п. Салгиру бас. затоки Сиваш на західному березі Азовського моря в Криму; Карасовка, Кара-Сy (1867) (СГУ: 240). Зазначений гідронім у сучасній формі є хрестоматійним прикладом наслідку народної етимології, зумовленої слов'янізацією за допомогою -івка незрозумілого іншомовного утворення Кара-Cy під впливом асоціативного зв'язку з широко вживаною назвою риби кара́сь за надуманою мотиваційною ознакою «річка, в якій водяться карасі». Насправді ж гідронім виник за кольоровою ознакою річки як композит на основі тюркського кара́ «чорний», можливо, «темний, джерельний» і $c y$ «вода». На відміну від тюркських мов, у яких прикметник кара «чорний» має як негативне, так і позитивне переносне (географічне або сакральне) значення, в українській мові чо́рний уживається лише з негативною семантикою, яка відбилася в багатьох топонімах.

Дискусійна етимологія деяких тюркських топонімів, що постали за внутрішніми ознаками об'єктів, може набути конкретизації завдяки їх зіставленню 3 суміжними українськими назвами. Так, назви рр. Кагарли́к у басейні Синюхи л. Пд. Бугу в Кіровоградській обл.; Кагарльљкъ (1705) і в басейні Дніпра в Київській 
обл.; Кагарлькъ (1890); пор. м. Кагарлик на річці (СГУ: 226) мають явно тюркське походження, але загальноприйнятого пояснення їхнього походження в науковій літературі не було вироблено. 3 огляду на взаємодію суфікса $-l y k$ у релятивній функції переважно з іменними основами топонім етимологізували як утворення від: 1) karga «ворон»; 2) карга «валун; накопичення валунів»; 3) карга, корга (монг. харга) з узагальненим значенням «кам'яниста річка»; 4) карга «тростник, тростниковий» (огляд див.: Лучик 1999: 39-40). Імовірнішим $є$ виникнення гідронімів за допомогою суфікса -lyk від д.тюрк. kögär «робитися синім, блакитним» (ДТС: 312), про що свідчать семантичні, словотвірні та фонетичні аргументи, а саме: 1) назви рр. Кагарли́к поширені в лісостеповій місцевості, де скупчені слов'янські гідроніми з основою Син- (< синій), яка вказує на блакитний колір прісної води, придатної для вживання; 2) зі словотвірного погляду дослідники відзначають, що в тюркських мовах і діалектах поширені віддієслівні топоніми на -ly/-li, -lyk/-lik, які, очевидно, пройшли через дієприкметникове посередництво (Донидзе 1964: $41)$; 3) гідроніми Кагарли́к на території України не мають жодного варіанта, який би засвідчив метатезу основи апелятивів карга, корга, що досі вважалися ймовірними твірними словами для назв річок.

Найбільше топонімів утворено за відношенням позначуваних об'єктів до інших (найчастіше суміжних) фізико-географічних чи створених людиною реалій навколишньої місцевості: Ташли́к - 1) річка, л. Чорного Ташлика л. Синюхи л. Пд. Бугу (ГЕУ 3: 266); 2) балка, л. Мокрої Волновахи п. Кальміусу, впадає в Азовське море; Ка́менная (1892) (СГУ: 556) - гідроніми постали як тюркські назви внаслідок онімізації відносного прикметника із суфіксом -lyk й основою апелятива таш «камінь; скеля; підвищення; гора» < д.тюрк. taš «камінь» (Мурзаев: 547) (усього в Україні зафіксовано близько півтора десятка назв річок 3 компонентом Ташли́к); м. Кілія́ в Одеській обл. (АТП: 328) має назву, яка виникла шляхом онімізації прикметника на -ли/-лі, -лий/лій з основою ГТ кил, кіл «гірська порода, різновид вибільних глин у Криму і на Кавказі», що в українській мові $\epsilon$ запозиченням з турецької, де kil походить від перс. gel «глина, болото, багнюка» (ЕСУМ 2: 432); семантика ГТ відбиває характер грунту в навколишній місцевості, а закінчення -я має слов'янську граматичну природу.

За відношенням до людини продовжували виникати насамперед ойконіми, адже населені пункти активно створювалися людьми і для людей. Так, м. Ізмайл в Одеській обл. (АТП: 328), яке з 1812 до 1856 р. належало Туреччині [ЕУ 3: 858], має назву, що виникла внаслідок трансонімізації турецького чол. імені Ismail, яке було означенням в ізафетній конструкції з опорним номенклатурним іменем аул, кой чи іншим зі значенням «поселення»; у східнослов'янському мовному середовищі твірний антропонім вимовляється як Ізмайл, рос. Измайл на місці вихідно-

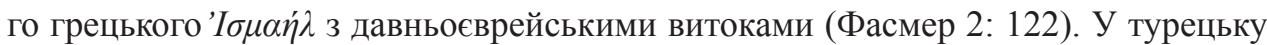
мову особове ім'я могло проникнути з арабської (Димитрова-Тодорова 2006: 382); пор. м. Ісмаілія в ОАР, назване за іменем турецького віце-короля Єгипту Ісмаїлаnami (Никонов: 162). Припущення Ю. О. Карпенка про те, що тюрк. Ismail це перетворене під антропонімним впливом давніше слов'янське Смил, Сміл 
(Карпенко 1977: 190), виглядає цілком аргументованим з огляду на існування на місці Ізмаӥла поселення зі слов'янською назвою, в основі якої псл. *smol- «смола; чорна земля» (ЕСТУ: 231), ще задовго до появи тут турків, а також на регулярне протетичне [i] в турецькій мові перед звукосполученням приголосних на початку слова; пор. слов'янське Cтамбул і турецьке Istanbul.

3-поміж топонімів, що виникли за відношенням до людини, досить поширеними в тюркських мовах є відетнонімні назви, які вказують на зв'язок географічних об'єктів з відповідними племенами чи народами. Таку ознаку опосередковано відбиває ойконім Печені́ги в Чугуївському р-ні Харківської обл., відомий 3 1646 р. (ГЕУ 3: 27). Очевидно, він мотивований давньоруською назвою території Печенъги, місц. Печенізьке поле, яку до XII ст. заселяли відповідні тюркські племена, що мали самоназву з основою д.тюрк. bес̌ӓnäk «печеніги» (ЕСТУ: 375-376). 3 огляду на відносно пізню фіксацію ойконіма ймовірною є його мотивація відетнонімним антропонімом Печеніг(a), який відбився в деяких топонімах України (Яцій 2007: 355-356).

Одним із яскравих прикладів творення топонімів на основі конотативних культурно-історичних або сакральних уявлень $є$ тюркська назва р. Бе́шка п. Інгульця п. Дніпра (СГУ: 47), яка виникла поєднанням числівника bes/beš «п’ять» і ГТ kaja «скеля» (Карпенко 1989: 126) за ознакою «річка зі скелястими берегами». Але числівник bes/beš «п’ять» має також сакральну семантику в мусульман, у топонімії яких він використовується у переносному значенні «богом дана множинність, святе число», що насамперед відбилося в зазначеному гідронімі; пор. релігійне n'ять світів, n'ять класів, n'ять елементів буття: золото, дерево, вода, земля, вогонь; п'ять видів членів тіла, створені богом (ДТС: 96-97), гідроніми Беста́ш, Беш-Байра́к, Бештерек (СГУ: 47), переважно південноукраїнські ойконіми П'ятиха́тки, які утворені під культурно-історичним впливом контактних тюркських народів. Українізація складеної назви *Беш кая шляхом ії трансформації в композит Бешка через стадію *Бешкая відбулася, очевидно, в козацькому середовищі XVI-XVIII ст. унаслідок аналогії до високопродуктивних у цей період топонімів на -к(а) (Лучик 1999: 31-32).

Тісні контакти українців і росіян 3 тюркськими народами та племенами на півдні України можуть ускладнювати етимологізацію топонімів 3 огляду на відсутність чітких ознак їх виникнення в тому чи тому мовному середовищі. Відповідно проблемним може бути не лише визначення мовної належності топоніма, а й достовірне встановлення принципу та мотиву номінації географічного об'єкта. Наприклад, досі залишається остаточно не з'ясованим походження хороніма Крим - назви Кри́мського піво́строва, що на заході та півдні омивається Чорним морем, а на північному сході - Азовським, територія колишньої Кримської обл., нині Кримська АР України (ГЕУ 2: 228-234). Були спроби пояснити хоронім на слов'янському грунті у зв'язку з крома «границя, межа», кремінь (Никонов: 217), пізніше - Kрылм з Кьрмъ < Къrmъ < псл. *Kъrmъ $<* k ъ r m-<$ i.є. $(s) k r$ - «гнути, згинати; кривити; крутити, вертіти», у рефлексі якого відбулася метатеза Кьрмъ > Крыль (Козлова 1997: 297]; пор. у зв’язку з цим мікротопонім 
Кримо́к на Чернігівщині (Черепанова: 152) та інші переважно поліські утворення 3 основою крим-. Але історія цього топоніма не підтверджує його праслов'янського чи навіть давньоруського походження. У документах Крим уперше згадується в XIII ст., коли на півострові володарювали монголо-татарські племена й турки. Ця назва з'явилася на позначення колишнього м. Caлxam у формі Eski Qirim, Eскі Крим, а в мові українців і росіян - Старий Крим. Із часом опорний компонент ойконіма Крим поширився на весь Кримський півострів і став його основною назвою (ГЕУ 2: 217; Суперанская 1995: 97; Бушаков 2003: 32]. Отже, найімовірнішим джерелом топоніма $є$ якась східна (очевидно, одна з тюркських) мова. Припускають, що твірним могло бути тюрк. кырым «рів, вал» 3 огляду на те, що вузький перешийок, який відділяє півострів від материкової України, був перекопаний рвом (пор. Переко́пський переши́йок), що має монгольський відповідник херем «фортечна стіна, вал» [Никонов: 217], або тур. і кр.тат. кӓрім «милостивий» (Радлов II/2: 1097). С й інші ймовірно твірні тюркські основи, але всі вони мають два відкриті склади, перший з яких не міг перетворитися у звукосполуку $K p$ - у панівному кримськотатарському й турецькому мовленні.

Системно проаналізувавши топоніми й антропоніми 3 «неповноголосною» основою Крим- (ойконіми Крымча, Крым-Шибань, Крым Эли в Криму, Крым у Малій Азії, антропоніми Крым, Кърым у караїмів, Крымса в туркменів, Крымхожа в узбеків-кипчаків, Крымтаевы у кримських мурз), дослідники підтверджують південно-східні (очевидно, поширені аж до українського полісся як караїмські) впливи на виникнення назви і припускають, що їі основа є генонімною, тобто була родовим іменем (Суперанская 1995: 97-98); пор. тюркські етноніми крымса «туркмени», крымхожа, крымходжа «узбеки (кипчаки)» (Лезина-Суперанская 2: 257).

Ще одним прикладом складної взаємодії контактних української та російської мов, з одного боку, з тюркськими мовами, з іншого боку, є згадуваний гідронім Інгу́л, який з приблизно однаковою імовірністю міг виникнути в тому чи тому мовному середовищі. Річка Інгу́л л. Пд. Бугу, яка протікає в Кіровоградській і Миколаївській обл., має варіанти назви Инкгулъ, Ингулъ (1697), Великий Ингулъ (1705), Angul, Angulet Wielki, Інгуль (1917) (СГУ: 222). Сучасна форма гідроніма Інгу́л, очевидно, $є$ тюркською фонетичною адаптацією праслов'янської або східнослов'янської назви ${ }^{*} Q g ъ l b$, утвореної семантичним способом від ГТ * $Q g ъ l b$, д.рус. угълъ, уголь «місцевість між річками, що сходяться» (Трубачев 1968: 206; Карпенко 1989: 43-53; Лучик 1996: 132-134). Носова вимова етимологічного $Q$ у тюркському мовленні передалася як $I n$ - або $A n$-, а лабіалізований -о- в основі розвинувся у голосний вищого піднесення $-y$ - внаслідок аналогії до тюрк. göl,

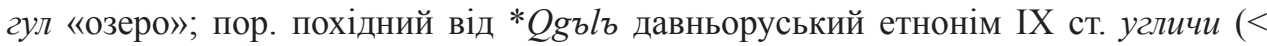
* Qgъlitje) (Лучик 1996: 132-135). Імовірним $є$ тюркське походження гідроніма від ängäl «тихий, лінивий», що відбиває характер течії степової річки, або від in «печера» чи $\ddot{n}$, in, en «широкий» i gol «озеро» (Фасмер 2: 131).

У посткозацьку (сучасну) добу суспільно відомі тюркські топоніми з'являлися рідко, бо тюркський вплив на географічні назви зберігався лише в слов'янізова- 
ному Криму, де продовжували виникати топоніми здебільшого кримськотатарського походження, та в Болградському районі Одеської обл., де проживає незначна частина гагаузів. Але в радянські часи на цих територіях, як і в усій Україні, більшість іншомовних назв (переважно ойконіми та урбаноніми) з ідеологічних міркувань було вольовим способом замінено на російські, тому тюркізми в топонімії останнього періоду є непродуктивними (відносно активно вони творяться в мікротопонімії відповідних регіонів). До відомих тюркських утворень середини XIX ст. належить назва м. Джанко́ú у Криму (ГЕУ 1: 318), яка виникла за внутрішніми ознаками поселення способом основоскладання тур. джан $<$ jäнi «новий, молодий» (Радлов III/1: 329) і кр.тат. кой «село, поселення» (Мурзаев: 282).

Отже, проникнення і функціонування тюркізмів у топонімії України протягом різних історичних періодів залежало від інтенсивності відповідних міграційних та колоніальних процесів, наслідком яких і були тюркомовні вкраплення в місцеву пропріальну лексику. Вони, як і автохтонні топоніми, виникали за трьома універсальними принципами: 1) за відношенням до людини; 2) за відношенням до інших об'єктів; 3) за внутрішніми властивостями та ознаками самого географічного об'єкта. Природні географічні назви тюркського походження в основному були адаптовані українською мовою та зберігаються здебільшого без істотних змін за природними об'єктами (річками, горами, урочищами, озерами і т. ін.), а в системі назв об'єктів, створених людьми (вулиць, поселень тощо), вони переважно були замінені радянськими меморіальними або іншими східнослов'янськими топонімами.

\section{Джерела}

Аркушин - АРКУШИН, Григорій Л. Словник західнополіських говірок: $y$ 2-x т. Луцьк: Вежа, 2000.

АТП - Украӥнська РСР. Адміністративно-територіальний поділ на 1 січня 1972 року (1973). Упоряд. Д. О. Шелягін. Київ: Вид-во політ. л-ри України, 1973.

Габорак - ГАБОРАК, Мирослав: Назви гір і полонин Івано-Франківщини: словник-довідник. - Вид. 2-е, доп., уточн. Івано-Франківськ: Місто НВ, 2008.

ГЕУ - Географічна енциклопедія Украӥни: В 3-х m. Відп. ред. О. М. Маринич. Київ: УРЕ ім. М. П. Бажана, 1989-1993.

ДТС - Древнетюркский словарь. Ленинград: Наука, 1979.

ЕСЛГНПР - Етимологічний словник літописних географічних назв Південної Русі. Гол. ред. О. С. Стрижак. Київ: Наук. думка, 1985.

ЕСТУ - ЛУЧИК, Василь В.: Етимологічний словник топонімів України. Київ: ВЦ «Академія», 2014.

ЕСУМ - Етимологічний словник украӥнської мови: В 7-ми т. Гол. ред. О. С. Мельничук. Київ: Наук. Думка, 1982-2012.

ЕУ - Енциклопедія українознавства: В 10-ти т. Львів: Наук. тов-во ім. Т. Шеченка, 1993. Т. 3. 
Лезина-Суперанская - ЛЕЗИНА, Ирина Н./Александра В. СУПЕРАНСКАЯ: Ономастика: словарь-справочник тюркских родоплеменных названий: в 2-х ч. Москва: ИНИОН РАН, 1994.

Мурзаев - МУРЗАЕВ, Эдуард М.: Словарь народных географических терминов. Москва: Мысль, 1984.

Никонов - НИКОНОВ, Владимир А.: Краткий топонимический словарь. Москва: Мысль, 1966.

Радлов - РАДЛОВ, Василий В.: Опыт словаря тюркских наречий: B 4-х Санкт-Петербург: ИАН, 1893-1911.

СГУ - Словник гідронімів України. Київ: Наук. Думка, 1979.

Севортян - СЕВОРТЯН, Эдуард В.: Этимологический словарь тюркских языков. Общетюркские и межтюркские основы на гласные. Москва: Наука, 1974.

Фасмер - ФАСМЕР, Макс: Этимологический словарь русского языка: В 4-х $m$. Пер. с нем. и доп. О. Н. Трубачева. - 2-е изд., стереотип. Москва: Прогресс, $1986-1987$.

Черепанова - ЧЕРЕПАНОВА, Евгения А. Микротопонимия ЧерниговскоСумского Полесья. Сумы: Сумский государственный педагогический институт им. А. С. Макаренко, 1984.

\section{Список літератури}

БУШАКОВ, Валерій А. (2003) Лексичний склад історичної топонімії Криму. Відп. ред. В. С. Рибалкін. Київ: Інститут сходознавства ім. А.Ю. Кримського НАНУ. ДИМИТРОВА-ТОДОРОВА, Лиляна (2006) Местните имена в Поповско. София: Акад. изд-во «Проф. Марин Дринов».

ДОНИДЗЕ, Гайоз И. (1964) «Глагольные топонимы в тюркских языках.» Топонимика Востока: Новые исследования. Ред. Г. А. Давыдова. Москва: Наука, 39-46.

ЖЕЛЕЗНЯК, Ірина М. 1987 Рось $і$ етнолінгвістичні прочеси Середньонаддніпрянського Правобережжя. Київ: Наук. думка.

КАРПЕНКО, Ольга П. (1989) Назви річок Нижньої Правобережної Наддніпрянщини. Київ: Наук. думка.

КАРПЕНКО, Юрий А. (1977) «Топонимы болгарских сел Одесской области (вопросы топонимического взаимодействия языков).» Историческая ономасти$\kappa a$. Отв. ред. А. В. Суперанская. Москва: Наука, 189-208.

КОЗЛОВА, Раиса М. (1997) Структура праславянского слова: Праславянское слово в генетическом гнезде. Гомель: Гомельский государственный университет им. Ф. Скорины.

ЛУЧИК, Василь В. (1996) Автохтонні гідроніми Середнього Дніпро-Бузького межиріччя. Кіровоград: Кіровоградський державний педагогічний інститут ім. В.К.Вииниченка.

ЛУЧИК, Василь В. (1999) Іншомовні гідроніми Середнього Дніпро-Бузького межиріччя. Кіровоград: Кіровоградський державний педагогічний інститут ім. В.К.Вииниченка. 
ТРУБАЧЕВ, Олег Н. (1968) Названия рек Правобережной Украины: Словообразование. Этимология. Этническая интерпретация. Москва: Наука.

ШУЛЬГАЧ, Віктор П. (1998) Праслов'янський гідронімний фонд (фрагмент реконструкиії). Київ: Інститут української мови НАН України.

ЯЦІЙ, Василь О. (2007) «Ойконімія Коломийського району Івано-Франківської області (матеріали до історико-етимологічного словника) II.» Студї̈ з ономастики та етимології. В.П. Шульгач (відп. ред.) та ін. Київ, 351-365.

\section{Аннотація \\ ТЮРКІЗМИ В ТОПОНІМІЇ УКРАЇНИ: ІСТОРИКО-ЕТИМОЛОГІЧНИЙ АСПЕКТ}

Багатовікові контакти тюркських племен і народів з корінним населенням України широко відбилися в іiі топонімії, у якій тюркізми становлять одну з найчисельніших груп з-поміж іншомовних географічних назв. Вони закріплювалися в місцевому мовленні протягом трьох основних періодів: 1) київськоруського (давньоукраїнського) - IX-XIII ст. (ур. і р. Срєль < тюрк. аірілі/аірылье «розділений», калька д.рус. Оуголь < уголь «кут; клин землі між річками, що сходяться»); 2) староукраїнського - XIV-XVIII ст. (терит. Буджак < тур. budžak «вугол»); 3) новоукраїнського (сучасного) - XIX-XXI ст. (м. Джанкой < тур. джан «новий» і кой «село, поселення»). Етимологія тюркських топонімів відбиває: внутрішні властивості географічних об'єктів (р. Аджиго́ль < аджи «киснути, бродити» і гол/голь «озеро, водойма»); відношення об'єктів номінації до інших (переважно суміжних) реалій навколишньої місцевості (м. Кілія́ < кіл «різновид вибільних глин» + суф. -лі/-лій у релятивній функції); відношення об'єктів до людини (м. Ізмaїл < чол. ім'я Ismail як колишній атрибутив в ізафетній конструкції). Похідні кожного з цих принципів номінації можуть виражати конотативне значення, пов'язане 3 культурно-історичними цінностями або сакральними уявленнями (р. Бе́шка < тюрк. bes/beš «п'ять», сакральне значення «богом дана множинність» і $k a j a$ «скеля»), які могли проникати і в контактне українське мовлення (пор. назву м. П'ятиха́тки, що виникла під тюркським культурологічним впливом). В останній (сучасний) період тюркський вплив на географічні назви зберігався головним чином у слов'янізованому Криму, де з'являлися топоніми здебільшого кримськотатарського походження, але в радянські часи на півострові, як і в усій Україні, більшість іншомовних назв (переважно ойконіми та урбаноніми), у тому числі і тюркських, була вольовим способом замінена.

Ключові слова: тюркізми, Україна, топоніми, етимологія, географічні назви, апелятив, історико-етимологічний 


\section{Abstract \\ TURKISMS IN THE TOPONYMY OF UKRAINE: HISTORICAL AND ETYMOLOGICAL ASPECTS}

The centuries-old contact of Turkic tribes with the native population of Ukraine is broadly reflected in Ukrainian toponymy where Turkisms are one of the largest groups among foreign place names. They embedded into the native speech during three main periods: 1) the Kievan Rus (Ancient Ukrainian) period $-9-13^{\text {th }}$ century (ravine and river Yeriel; < Turkic airily/airyly 'divided', Old Russian calque Оуголь < уголь 'angle; land wedge between converging rivers'); 2) the Old Ukrainian period $-14-18^{\text {th }}$ century (territory of Budzhak < Turkic budzhak 'angle'); 3) the New Ukrainian (Modern) period - 19-21 $1^{\text {st }}$ century (city of Dzhankoy < Turkic dzhan 'new' and koy 'village, settlement'). The etymology of Turkic toponyms reflects the following: inherent properties of geographical elements (river Adzhyhol' < adzhy 'sour, ferment' and hol/hol' 'lake, water body'); relations of the elements denoted to other (mainly adjacent) surrounding elements (city of Kiliya $<$ kil 'sort of bleaching clays' + suffix -li/-liy in relative function); relation to people (city of Izmail < male name Ismail as former attributive in the Ezafe construction). Derivatives of each of these toponymic principles may be used to express cultural and historical values or religious aspects (the river Beshka $<$ Turkic bes/beş 'five', sacred meaning 'god given plurality' and kaja 'rock') that may permeate Ukrainian contact speech (compare the name of the town Pyatykhatky that came into use under the Turkic cultural influence). In the last (Modern) period, the Turkic influence on the geographical names remained mainly in Slavicized Crimea where the toponyms were for the most part of Crimean Tatar origin. However, in the Soviet time the majority of foreign names (principally oikonyms and urbanonyms), including Turkic ones, on the peninsula as well as in the whole of the Ukraine were deliberately changed.

Keywords: Turkisms, Ukraine, toponyms, etymology, geographical names, appellative, historical-etymological studies

\section{Povzetek \\ TURCIZMI V TOPONIMIJI UKRAJINE: ZGODOVINSKO-ETIMOLOŠKI VIDIK}

Večstoletni stiki turko-tatarskih plemen in narodov s prvotnim prebivalstvom Ukrajine so se v precejšnji meri odrazili tudi v njeni toponimiji. Turcizmi predstavljajo eno najštevilnejših skupin med tujejezičnimi zemljepisnimi imeni. V lokalnem govoru so se ustalili v treh osnovnih obdobjih: 1) kijevskoruskem (protoukrajinskem) - 9-13. stol. (reka Єрєль < tur. airili/airyly 'razdeljen', kalk strus. Оуголь < уголь 'kot; zemljišče v obliki klina med dvema rekama, ki se stekata'); 2) staroukrajinskem - 14.-18. stol. (horonim Буджак < tur. budžak 'vogal, kot'); 3) novoukrajinskem (sodobnem) - 19.-21. stol. (mesto Джанкой < tur. $d \check{z} a n$ 'nov' in $k o j$ 'vas, naselje'). Etimologija turko-tatarskih toponimov odraža: notranje lastnosti geografskih objektov (reka Аджиго́ль < adži 'kisati 
se, vreti' in gol/gol ' 'jezero, vodni zbiralnik'); odnos poimenovanih objektov do drugih (navadno bližnjih) realij okolice (mesto Kiлiǵ < kil 'vrsta belilne gline' + sufiks -li/-lij v oziralni funkciji); odnos objektov do človeka (mesto Ізмaḯl < os. i. Ismail kot nekdanji prilastek v t.i. izafetni konstrukciji). Izpeljanke vsakega od teh principov nominacije lahko izražajo konotativni pomen, povezan s kulturno-zgodovinskimi vrednostmi ali sakralnimi predstavami (reka Бе́шка < tur. bes/bеš 'pet', sakralni pomen 'od boga dano mnoštvo' in kaja 'skala'), ki so lahko prodirali tudi v kontaktni ukrajinski govor (prim. ime mesta П’ятиха́тки, ki je nastalo pod turko-tatarskim kulturološkim vplivom). V zadnjem (sodobnem) obdobju se je turko-tatarski vpliv na zemljepisna imena ohranjal predvsem na slovaniziranem Krimu, kjer so se pojavljali toponimi pretežno krimskotatarskega izvora, vendar je bila v sovjetskem obdobju na polotoku, tako kot $\mathrm{v}$ vsej Ukrajini, večina tujejezičnih imen (predvsem naselbinska imena in imena mestnih predelov), med njimi tudi turko-tatarska, administrativno spremenjena.

Ključne besedes: turcizmi, Ukrajina, toponimi, etimologija, zemljepisna imena, občna imena, zgodovinsko-etimološko raziskovanje 